\title{
Osteonecrosis of the femoral heads in patients with systemic onset juvenile idiopathic arthritis: comparison of the results of radiological and morphological methods
}

D Alexeev, I Nikishina*, A Smirnov, L Semenova, L Bogjeva, S Makarov, S Radenska-Lopovok, D Ivanov

From 18th Pediatric Rheumatology European Society (PReS) Congress

Bruges, Belgium. 14-18 September 2011

\section{Background}

The destruction of the hip joints with the development of osteonecrosis $(\mathrm{ON})$ - a common complication and a leading cause of functional impairment in patients with systemic onset juvenile idiopathic arthritis (soJIA).

\section{Aim}

A detailed study of the character of local disturbances and the structure of femoral heads (FH) in soJIA according to the comprehensive radiologic and morphological studies.

\section{Methods}

Four patients with similar clinical and demographic characteristics (female, age 17-20 years, soJIA, disease duration $>10$ years, the duration of hip damage $>5$ years), underwent total hip replacement (5 hip joints), because of $\mathrm{ON}$ of the $\mathrm{FH}$. Changes in the $\mathrm{FH}$ were

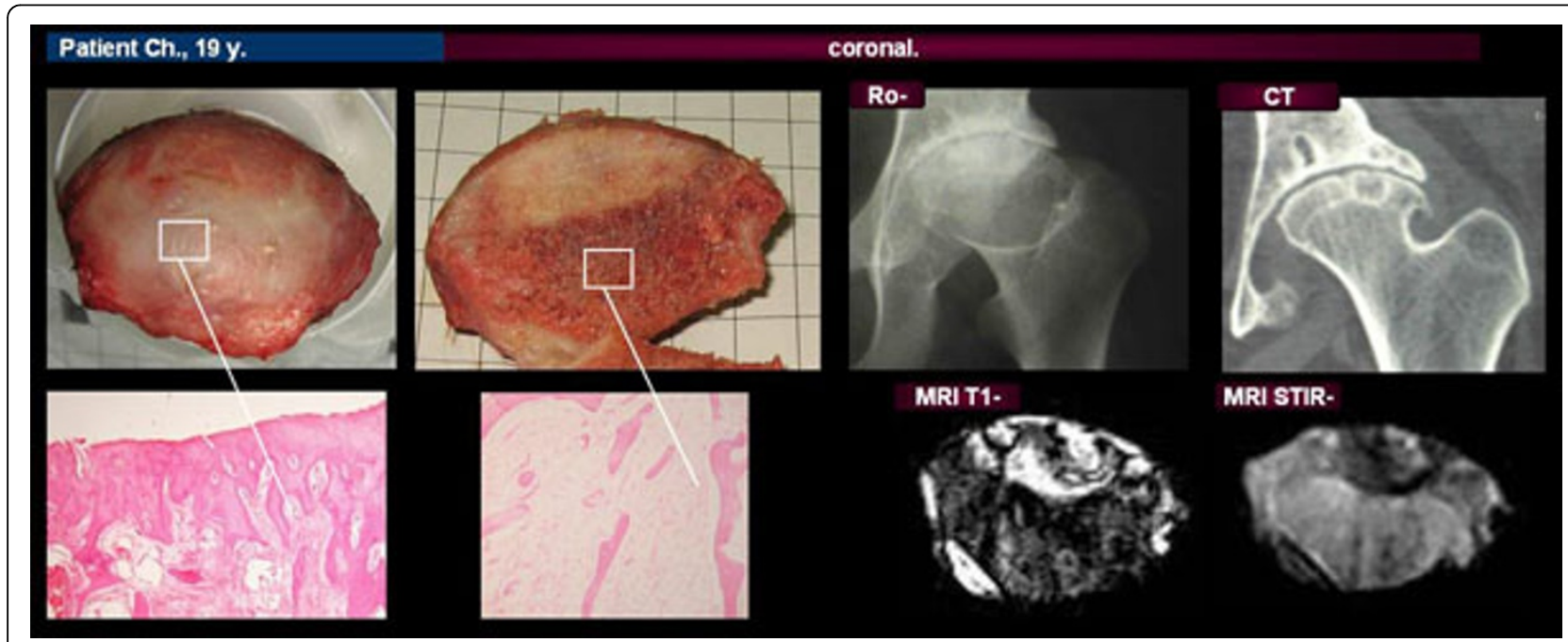

Figure 1

Research Institute of Rheumatology of Russian Academy of Medical Sciences,

Moscow, Russian Federation 
investigated using a specially designed protocol with the use of radiologic (conventional radiography (Ro), computed tomography $(\mathrm{CT})$, magnetic resonance imaging (MRI)) and morphological techniques.

\section{Results}

Ro-, CT revealed pronounced joint space narrowing, the picture of osteonecrosis with FH deformation, realignment of bone structure, erosions. Zones with significant restructuring of the bone (detected by $\mathrm{CT}$ ) and enhanced heterogeneous MRI signal (T1-, T2- weighted) were characterized by diverse damage in cartilaginous and bone tissues at morphologic examination (fissures in cartilage; cysts, sclerosis, necrosis of trabecular bone).

\section{Conclusion}

The results show that in patients soJIA with destructive hip damage similar changes of $\mathrm{FH}$, interpreted by the radiological methods as $\mathrm{ON}$, are characterized by a variety of histological disorders. Further in-depth comprehensive study of bone structure, damaged by $\mathrm{ON}$ of the $\mathrm{FH}$ will promote understanding of the pathogenetic nature of this complication.

Published: 14 September 2011

doi:10.1186/1546-0096-9-S1-P134

Cite this article as: Alexeev et al:: Osteonecrosis of the femoral heads in patients with systemic onset juvenile idiopathic arthritis: comparison of the results of radiological and morphological methods. Pediatric

Rheumatology 2011 9(Suppl 1):P134.
Submit your next manuscript to BioMed Central and take full advantage of:

- Convenient online submission

- Thorough peer review

- No space constraints or color figure charges

- Immediate publication on acceptance

- Inclusion in PubMed, CAS, Scopus and Google Scholar

- Research which is freely available for redistribution

Submit your manuscript at www.biomedcentral.com/submit
C Biomed Central 